\title{
Maternal Perception of the Child's Weight, Lifestyle Problems and Self-Efficacy to Deal with Them
}

Topic: Promotion and prevention.

Contribution to the subject: Nursing can participate in the promotion of adequate maternal perception of the child's weight and enhance self-efficacy in mothers of children with overweight-obesity, who perceive more lifestyle behavior problems and less self-efficacy to deal with them.

\section{ABSTRACT}

Objectives: To associate the maternal perception of the child's weight (MPCW) and the child's nutritional status. To describe child's lifestyle behavior problems (CLBPs) and maternal self-efficacy (SE) to deal with them, as well as to verify differences according to children with and without overweight-obesity (OW-OB) and MPCW. Material and methods: There was participation of 274 dyads (motherpreschool child). MPCW was assessed through words and images. The mothers answered the Lifestyle Behaviour Checklist. The child's weight and height were measured. Results: $18.8 \%(n=13)$ of the mothers of children with OW-OB and $78.8 \%(n=160)$ of the mothers of children without $\mathrm{OW}-\mathrm{OB}$ obtained adequate MPCW values through words $\left(X^{2}=77.759 ; D o F=1 ; p<.001\right)$. It was identified that the mothers of children with OW-OB reported more CLBPs and less SE. When the child's OW-OB is perceived through words, there are more $\operatorname{CLBPS}(F=17.041 ; p=.001)$ and less SE $(U=1,118 ; p=.015)$. Conclusions: Inadequate MPCW was predominant in mothers of children with $\mathrm{OW}-\mathrm{OB}$. When $\mathrm{OW}-\mathrm{OB}$ is perceived, there are more CLBPs and fewer SE. It is recommended to promote adequate MPCW, particularly in mothers of children with $\mathrm{OW}-\mathrm{OB}$. Images assist in the identification of the child's OW-OB more than to classify it into a category.

\section{KEYWORDS (SOURCE: DeCS)}

Weight perception; self-efficacy; problem behavior; obesity; preschool child.

DOI: 10.5294/aqui.2021.21.2.8

To reference this article / Para citar este artículo / Para citar este artigo

Flores-Peña Y, Ávila-Alpirez H. Maternal Perception of the Child’s Weight, Lifestyle Problems and Self-Efficacy to Deal with Them. Aquichan. 2021;21(2):e2128. DOI: https:// doi.org/10.5294/aqui.2021.21.2.8

1 \https://orcid.org/0000-0001-6200-6553. Universidad Autónoma de Nuevo León, Mexico. yolanda.florespe@uanl.edu.mx

2 https://orcid.org/0000-0001-5286-5944. Universidad Autónoma de Tamaulipas, Mexico. havila@docentes.uat.edu.mx 


\section{Percepción materna del peso del hijo, problemas del estilo de vida y autoeficacia para manejarlos}

\section{RESUMEN}

Objetivos: asociar la percepción materna del peso del hijo (PMPH) y estado nutricional del hijo. Describir problemas conductuales del estilo de vida del hijo (PCEV) y autoeficacia materna (AE) para manejarlos, verificar diferencias conforme a con y sin sobrepeso-obesidad (SP-OB) del hijo y PMPH. Material y métodos: participaron 274 diadas (madre-hijo preescolar). La PMPH se evaluó por palabras e imágenes. Las madres contestaron la Lista de Verificación de Conductas del Estilo de Vida. Se midió peso y talla del hijo. Resultados: $18.8 \%$ $(n=13)$ madres de hijos con SP-OB y $78.8 \%(n=160)$ madres de hijos sin SP-OB tuvieron PMPH adecuada por palabras $\left(X^{2}=77.759\right.$, $g l=1, p<.001)$. Las madres de hijos con SP-OB tuvieron que manejar más baja AE y más PCEV. Cuando las madres perciben el SP-OB del hijo por palabras, tienen menor AE $(U=1118, p=.015)$ y más PCEV $(F=17.041, p=.001)$. Conclusiones: Predominó PMPH no adecuada en madres de hijos con SP-OB. Cuando se percibe el SP-OB, más PCEV y menor AE. Se recomienda promover PMPH adecuada particularmente en madres de hijos con SP-OB. Las imágenes ayudan a reconocer el SP-OB del hijo más que a clasificarlo en una categoría.

PALABRAS CLAVE (FuENTE: DeCS)

Percepción del peso; autoeficacia; problema de conducta; obesidad; preescolar. 


\section{Percepção materna do peso do fillho, problemas do estilo de vida e autoeficácia para lidar com eles}

\section{RESUMO}

Objetivos: associar a percepção materna do peso do filho (PMPF) e o estado nutricional dele. Descrever problemas comportamentais do estilo de vida do filho (PCEV) e autoeficácia materna (AE) para lidar com eles, verificar diferenças entre com e sem excesso de pesoobesidade (EP-OB) do filho e PMPF. Materiais e métodos: participaram 274 díades (mãe-filho em idade pré-escolar). A PMPF foi avaliada por meio de palavras e imagens. As mães responderam à Lista de Verificação de Comportamentos do Estilo de Vida. Peso e altura do filho foram medidos. Resultados: 18,8 \% ( $n=13)$ mães de filos com EP-OB e 78,8 \% $(n=160)$ mães de filhos sem EP-OB tiveram PMPF adequada por palavras $\left(X^{2}=77.759 ; \mathrm{gl}=1 ; p<, 001\right)$. Foi identificado que as mães de filhos com EP-OB referiram mais PCEV e menos AE. As mães de filhos com EP-OB tiveram que lidar com mais baixa AE e mais PCEV. Quando as mães percebem o EP-OB do filho por palavras, têm menos $A E(U=1118, p=, 015)$ e mais PCEV $(F=17,041, p=, 001)$. Conclusões: PMPF não adequada predominou em mães de filhos com EP-OB. Quando o EP-OB é percebido, mais PCEV e menos AE. Promover PMPF adequada particularmente em mães de filhos com EP-OB é recomendado. As imagens ajudam a reconhecer o EP-OB do filho mais do que a classificá-lo numa categoria.

PALAVRAS-CHAVE (FonTE: DeCS)

Percepção de peso; autoeficácia; comportamento problema; obesidade; pré-escolar. 


\section{Introduction}

Childhood obesity is one of the most severe public health problems of the $21^{\text {st }}$ century. Its prevalence has been increasing at an alarming pace. In 2016, more than 41 million children aged less than 5 years old worldwide were overweight or obese (1). Multiple factors contribute to excess weight during childhood, such as high consumption of fat and sugar and reduced physical activity (2), as well as false traditional beliefs regarding health and nutrition (3).

Excess weight during childhood has repercussions on health, such as hyperlipidemia, hypertension, and abnormal tolerance to glucose. In addition, it has been documented that an overweight 5-year-old child has 4 times more chances of presenting obesity at the age of 9 when compared to a child with normal weight at the same age (4).

During childhood, and according to the traditional gender role, the mother is the main caregiver (5), the reason why she is in a unique position to exert an influence on her child's lifestyle behaviors. However, the literature has documented that the mothers of overweight-obese children have an inadequate perception of the child's weight: they underestimate it (6-10). Therefore, they could be less willing to motivate them to participate in healthy behaviors and less likely to resort to health services (6). Likewise, it has been documented that the mothers of children aged between 2 and 6 years old present more chances of underestimating overweight and obesity in their children (9).

Assessing how the mother perceives her child's body weight is a previous step to involving her in programs to prevent and treat excess weight in childhood. The maternal perception of the child's weight (MPCW) is the mother's opinion regarding the child's body weight, formulated based on the recognition of body size, standards related to body weight, health and beliefs associated with upbringing (11).

In addition, it has been documented that mothers of children with overweight-obesity need to deal with the children's lifestyle behavior problems (CLBPs) linked to childhood obesity, such as: demanding extra helpings at meals or watching too much television; and they report less self-efficacy (SE) to deal with these problems when compared to the mothers of children with normal weight (12-14). Self-efficacy allows the caregiver, in this case, the mother, to perceive her own ability and competence to exert a positive influence on the children's behaviors, upbringing and development. The concept of self-efficacy was proposed by Bandura in 1977 as a core cognitive element to explain the acquisition, maintenance and changes of human behavior, along with other variables of the Social Cognitive Theory (15).

As already pointed out, most of the mothers of children with overweight-obesity present inadequate MPCW; in addition, they have fewer chances of participating in programs to lose weight (6), as well as less motivation to help the children reduce their body weight and foster healthy behaviors (16). On the other hand, several studies conducted with adolescents and adults have found that an adequate perception of overweight-obesity is associated with depression and with unhealthy behaviors that could favor weight gain (17). However, up to date, it has not been explored if the CLBPs and SE to deal with them differ according to an adequate maternal perception of overweight-obesity in preschool children.

Given the above, this research study was conducted with the following objectives: 1) to associate MPCW with the child's nutritional status, 2) to describe the CLBPs and verify if they differ according to children with and without overweight-obesity, 3) to describe SE and verify if it differs according to children with and without overweight-obesity; and 4) to evaluate if the CLBPs and SE differ according to MPCW.

Given that Nursing is the first contact of the user with the health services, it is considered that the knowledge that is generated could ground Nursing actions targeted at preventing and treating childhood overweight-obesity, promoting adequate MPCW, and implementing actions targeted at reducing the CLBPS that are identified, as well as offering strategies to strengthen SE to deal with them.

\section{Material and methods}

\section{Design}

A correlational and cross-sectional study.

\section{Inclusion criteria}

Women who identified themselves as mothers of preschool children enrolled in the selected educational institutions. 
Women who were able to read and write to answer the questionnaires.

\section{Exclusion criteria}

Questionnaires in which the mothers reported that the preschool children had some diseases affecting their development, such as endocrine disease and asthma.

\section{Participants and Sample}

The participants were preschool children and their mothers, the latter being recruited for having their children enrolled in 4 public educational institutions attended by 524 preschoolers. Recruitment was conducted in 2016 and the institutions belonged to School Zone No. 1 of the metropolitan area of Monterrey, Nuevo León, Mexico. The zone was randomly selected from the list provided by the Public Education Secretariat.

To calculate the sample, the nQuery Advisor package, version 4.0, was used for means comparison of SE according to MPCW with and without $\mathrm{OW}-\mathrm{OB}$, a bilateral significance level of .05 and power of 95, which resulted in 270 participants. Subsequently, using cluster-stratified sampling, where the schools were the strata and the groups were the clusters, the groups were randomly selected, and 300 mothers were invited to participate. A total of 274 dyads (mother-preschool child) were considered for the analysis; the questionnaires in which the mothers reported that the children had some disease $(n=8)$ were excluded, as well as incomplete questionnaires $(n=12)$ or those with duplicate answers $(n=6)$.

\section{Study Variables and Measurements}

MPCW was the mother's perception regarding her preschool child's weight, which was assessed through two methods. In the first, called perception through words, the mothers answered the following question: "I believe that my child is", with the following answer options: a) "underweight", b) "slightly underweight", c) "around normal weight", d) "slightly overweight", and e) "overweight". This corresponds to the Physical Appearance and Health Perceptions Questionnaire (18); it was considered adequate when the mother's report was in agreement with the nutritional status assessed in the child (19). It is worth noting that, in the mothers of children with overweight-obesity, when inadequate MPCW is present it corresponds to underestimation; regarding the mothers of children with low or normal weight, it can present underestimation or overestimation.
In addition, MPCW was assessed through images with a panel containing 7 images according to the child's gender and age (18). It was considered adequate when a) the mothers of children with low weight selected images 1 and 2 to the right, b) the mothers of children with normal weight selected images 3,4 , or 5 in the center, and c) the mothers of children with overweight-obesity selected images 6 or 7 to the left.

The mothers also answered the Lifestyle Behaviour Checklist questionnaire (12), which presents 25 different child's lifestyle behaviors related to childhood obesity. They are asked to indicate to what extent each of these behaviors represents a problem, for example: demands extra helpings at meals, with Likert-type answers, namely: 1) Not at all, 2) and 3) A little, 4) Somewhat, 5) and 6) Very much, and 7) A lot, with a minimum score of 25 and a maximum score of 175 , where higher scores indicate that the behavior is perceived as a problem.

Subsequently, they are asked to select from 1 to 10 to indicate how confident they feel to deal with each of the behaviors, where 1 represents no confidence and 10 means feeling confident. In case the behavior is not occurring, they are asked to indicate how confident they feel that they could deal with it if it did occur; the minimum score is 25 and the maximum score is 250 , where higher scores represent greater self-efficacy. This questionnaire has reported Cronbach's alpha values of 0.97 for the BP subscale and 0.92 for the SE scale.

Preschooler nutritional status was the preschool child's Body Mass Index classified in percentiles according to what is set forth by the WHO (19), namely: malnutrition (< percentile 3 ), low weight ( $\geq 3$ and $<15$ ), normal weight $(\geq 15$ and $<85$ ), overweight ( $\geq 85$ but $<97$ ) and obesity $(\geq 97$ ). Weight was measured in kilograms with a $0.1 \mathrm{~kg}$ precision Seca 804 scale and was divided by the square of the height expressed in meters, which was measured with a Seca 214 stadiometer. In addition, sociodemographic information such as maternal age, schooling and occupation was asked, as well as the child's age and gender by requiring the presentation of a sociodemographic information card.

\section{Data analysis}

The data were captured and analyzed in the Statistical Package for the Social Sciences (SPSS) for Windows statistical pro- 
gram, version 21.0. The reliability of the Lifestyle Behaviour Checklist questionnaire (12) was assessed using Cronbach's alpha coefficient and the descriptive statistics of the sociodemographic information were obtained.

For Objective 1 (to associate MPCW with the child's nutritional status), a 2x2 contingency table was prepared with adequate and inadequate MPCW and the child's nutritional status according to children with and without overweight-obesity, and the chi-square test was applied. For Objective 2 (to describe the CLBPs and verify if they differ according to children with and without overweightobesity), Objective 3 (to describe SE and verify if it differs according to children with and without overweight-obesity) and Objective 4 (to evaluate if the CLBPS and SE differ according to MPCW), the distribution of the CLBPS and SE variables was verified using the Kolmogorov-Smirnov test with Lilliefors correction and, according to this, parametric and non-parametric statistics were applied.

The single-factor ANOVA test was applied for Objective 2. According to Objective 3, the Mann-Whitney $U$ test was applied and, according to Objective 4, the sum of CLBPs and SE was considered; in addition, the single-factor ANOVA test and the MannWhitney $\mathrm{U}$ test were applied, respectively.

\section{Ethical considerations}

This research was reviewed and approved by an Ethics Committee, registered with No. 12CEI19039007 at the Federal Commission for the Protection against Health Risks, and observed the Ethical Standards outlined in the 1973 Declaration of Helsinki.

The participating mothers were explained the research objectives and the procedures to be performed, as well as the risks and benefits inherent to participation in the study. They were guaranteed freedom to withdraw their consent at any time of the study, without this representing negative consequences for them or their children. Anonymity and confidentiality of the information were ensured, in addition to guaranteeing that the data would only be analyzed and handled jointly; subsequently, the mothers signed the informed consent. Assent was also obtained from the preschool children to perform the anthropometric measurements, which were in charge of qualified and standardized health staff that preserved the preschool children's integrity and privacy. Data collection was conducted in educational institutions.

\section{Results}

The internal consistency of the two subscales of the Lifestyle Behaviour Checklist (12) was assessed using Cronbach's alpha coefficient; both subscales presented acceptable reliability: CLBPs, $a=0.78$ and SE, $a=0.94$.

There was participation of 274 dyads (mother-child), with a mean maternal age of 30.79 years old $(S D=5.9)$ and a mean schooling of 11.19 years of study $(S D=3.01) ; 82.5 \%(n=226)$ lived with their partner; and $62.4 \%(n=171)$ were housewives. Regarding the children, their mean age was 4.38 years old $(S D=0.69), 54.4 \%(n=149)$ were female, mean weight of $18.90 \mathrm{~kg}(S D=3.66)$, mean height of $108.83 \mathrm{~cm}(S D=6.80)$, and $25.2 \%(n=69)$ with overweight-obesity; the information is presented in Table 1.

Table 1. Descriptive statistics of the sociodemographic and anthropometric characteristics of the participating dyads

\begin{tabular}{|c|c|}
\hline \multicolumn{2}{|c|}{ Maternal Characteristics $(n=274)$} \\
\hline Mean age (Standard Deviation) & $30.79(5.9)$ \\
\hline Mean schooling in years (Standard Deviation) & $11.19(3.01)$ \\
\hline Mean family income in MXN (Standard Deviation) & $9,726.10(7,343.75)$ \\
\hline $\begin{array}{l}\text { Marital status }(\mathrm{n}, \%) \\
\text { Married or lives with her partner }\end{array}$ & $226(82.5 \%)$ \\
\hline Occupation (n, \%) Housewife & $171(62.4)$ \\
\hline \multicolumn{2}{|c|}{ Child's Characteristics $(n=274)$} \\
\hline Mean age (Standard Deviation) & $4.38(.69)$ \\
\hline \multicolumn{2}{|l|}{ Gender } \\
\hline Female $(n, \%)$ & 149 (54.4) \\
\hline Male (n, \%) & $125(45.6)$ \\
\hline \multicolumn{2}{|l|}{ Anthropometric measures } \\
\hline Mean weight (Standard Deviation) & $18.9(3.66)$ \\
\hline Mean height (Standard Deviation) & $108.83(6.80)$ \\
\hline \multicolumn{2}{|l|}{ Nutritional status } \\
\hline With overweight-obesity (n, \%) & $69(25.18)$ \\
\hline Without overweight-obesity (n, \%) & 205 (74.82) \\
\hline
\end{tabular}

Source: Own elaboration 


\section{Statistics to verify the study objectives}

According to Objective 1 , adequate MPCW through words was found in $18.8 \%(n=13)$ of the mothers of children with overweight-obesity and in $78.8 \%(n=160)$ of the mothers of children without overweight-obesity $\left(X^{2}=77.759 ; D o F=1 ; p<.001\right)$. Through images, adequate MPCW was found in $2.9 \%(n=2)$ of the mothers of children with overweight-obesity and in $44.4 \%(n=91)$ of the mothers of children without overweightobesity $\left(X^{2}=39.638 ; D o F=1 ; p<.001\right)$; the information is presented in Table 2.

It was found that 10 behavior problems are more frequent in preschool children with overweight-obesity; the information is presented in Table 3.
Table 2. MPCW through words and through images according to the child's nutritional status

\begin{tabular}{|c|c|c|}
\hline \multicolumn{3}{|c|}{ Child's nutritional status } \\
\hline MPCW through words & $\begin{array}{c}\text { With } \\
\text { overweight-obesity }\end{array}$ & $\begin{array}{c}\text { Without } \\
\text { overweight-obesity }\end{array}$ \\
\hline Adequate & $13(18.8 \%)$ & $160(78.0 \%)$ \\
\hline Inadequate & $56(81.2 \%)$ & $45(22.0 \%)$ \\
\hline MPCW through images & $X^{2}=77.759 ; D o F=1 ; p<.001$ \\
\hline Adequate & $\begin{array}{c}\text { With } \\
\text { overweight-obesity }\end{array}$ & $\begin{array}{c}\text { Without } \\
\text { overweight-obesity }\end{array}$ \\
\hline Inadequate & $2(2.9 \%)$ & $91(44.4 \%)$ \\
\hline & $67(97.1 \%)$ & $114(55.6 \%)$ \\
\hline
\end{tabular}

Source: Own elaboration

Table 3. Single-factor ANOVA test for the child's lifestyle behavior problems according to children with and without overweight-obesity

\begin{tabular}{|l|c|c|c|c|c|}
\hline \multirow{2}{*}{\multicolumn{1}{|c|}{ Behavior Problem }} & \multicolumn{2}{c|}{ With OW-OB } & \multicolumn{2}{c|}{ Without OW-OB } & \multirow{2}{*}{$\boldsymbol{p}$} \\
\cline { 2 - 4 } & Mean & SD & Mean & SD & \\
\hline 1. Eats too quickly & 2.94 & 1.34 & 2.60 & 1.21 & .050 \\
\hline 2. Eats too much & 3.26 & 1.37 & 2.99 & 1.27 & .137 \\
\hline 3. Eats unhealthy snacks & 3.30 & 1.34 & 3.16 & 1.28 & .413 \\
\hline 4. Whinges or whines about food & 2.39 & 1.46 & 2.32 & 1.50 & .721 \\
\hline 5. Yells about food & 1.97 & 1.43 & 1.66 & 1.20 & .077 \\
\hline 6. Throws a tantrum about food & 2.33 & 1.56 & 2.00 & 1.33 & .084 \\
\hline 7. Refuses to eat certain foods & 3.22 & 1.93 & 3.01 & 1.71 & .411 \\
\hline 8. Argues about food & 2.39 & 1.62 & 1.66 & 1.15 & .001 \\
\hline 9. Demands extra helpings at meals & 2.67 & 1.51 & 2.22 & 1.24 & .017 \\
\hline 10. Requests food continuously between meals & 3.29 & 1.33 & 3.24 & 1.47 & .800 \\
\hline 11. Demands food when shopping or on outings & 3.32 & 1.65 & 3.09 & 1.62 & .321 \\
\hline 12. Sneaks food when they know they are not supposed to & 1.90 & 1.43 & 1.29 & .78 & .001 \\
\hline 13. Hides food & 1.55 & 1.32 & 1.08 & .02 & .001 \\
\hline 14. Steals food from other children & 1.28 & 1.13 & 1.14 & .80 & .680 \\
\hline 15. Eats food to comfort themselves when feeling let down or depressed & 1.74 & 1.55 & 1.24 & .90 & .001 \\
\hline 16. Watches too much television & 3.70 & 1.87 & 3.17 & 1.46 & .018 \\
\hline
\end{tabular}




\begin{tabular}{|l|c|c|c|c|c|}
\hline \multicolumn{1}{|c|}{ Behavior Problem } & \multicolumn{2}{c|}{ With OW-OB } & \multicolumn{2}{c|}{ Without OW-OB } & \multirow{2}{*}{$\boldsymbol{p}$} \\
\cline { 2 - 5 } & Mean & SD & Mean & SD & \\
\hline 17. Spends too much time playing video or computer games & 3.12 & 1.77 & 2.36 & 1.46 & .001 \\
\hline 18. Complains about doing physical activity & 1.94 & 1.27 & 1.65 & 1.13 & .78 \\
\hline 19. Refuses to do physical activity & 1.71 & 1.17 & 1.48 & 1.50 & .183 \\
\hline 20. Complains about being unfit & 1.26 & .67 & 1.20 & .65 & .473 \\
\hline 21. Complains about being overweight & 1.14 & .55 & 1.04 & .24 & .039 \\
\hline 22. Complains about being teased & 1.41 & 1.07 & 1.26 & .90 & .281 \\
\hline 23. Complains about not having enough friends & 1.67 & 1.29 & 1.36 & .83 & .022 \\
\hline 24. Complains about being unattractive & 1.10 & .54 & 1.04 & .22 & .221 \\
\hline 25. Complains about not fitting into clothes & 1.46 & 1.23 & 1.24 & .75 & .074 \\
\hline
\end{tabular}

${ }^{*}$ Note: $O W-O B=$ Overweight-Obesity; $S D=$ Standard Deviation; $F=$ Variance; $p=$ Significance

Source: Own elaboration

According to Objective 3 , it was found that the mothers of children with overweight-obesity presented less self-efficacy when compared to the mothers of children without overweight-obesity to deal with 15 of the 25 behavior problems; the information is presented in Table 4.

Finally, regarding Objective 4, Table 5 shows that, when MPCW through words is adequate, the mean of CLBPs is higher $(\bar{X}=63.14 ; S D=18.14)$. When compared to the mean of inadequate MPCW $(\bar{X}=49.67 ; S D=11.49 .14)$, the difference was significant. No significant difference was found in MPCW through images.

Regarding SE, it was found that, when MPCW is adequate, the mothers' SE is lower $(M R=87.36)$ when compared to the mothers with inadequate MPCW $(M R=140.20)$, and the difference was significant $(U=1,118 ; p=.015)$. No significant difference was found in MPCW through images; the information is presented in Table 6.

\section{Discussion}

This study assessed MPCW, as well as the CLBPs and SE to deal with them, and it was verified if they differ according to MPCW. It was found that most of the mothers of children with overweight-obesity present inadequate MPCW, perceive more
CLBPs and have less SE. When the perception of the child's overweight-obesity is adequate, higher CLBP scores and lower SE values are presented.

As already mentioned, inadequate MPCW was present in most of the mothers of children with overweight-obesity, which indicates that they underestimate their children's weight. This finding is consistent with what is reported in other studies and systematic reviews of studies conducted in countries such as Australia, Germany, Italy, United States, Brazil, United Kingdom and Singapore, among others (7-10). Therefore, the results of this study confirm the existing evidence.

The CLBP and SE variables were assessed using the Lifestyle Behaviour Checklist questionnaire (12), which presented acceptable internal consistency, similarly to what is published in the literature regarding the population living in Australia (13), the Netherlands (14) and Mexico (20). It is worth pointing out that, to the present day regarding research, this questionnaire is the only one that assesses SE to deal with CLBPs; likewise, the authors have indicated that assessing self-efficacy for a specific behavior is the best SE indicator, which would allow working to reinforce it (15).

It was found that the mothers of children with overweightobesity reported more CLBPs and less SE when compared to the mothers of children without overweight-obesity, which is similar 
Table 4. Mann-Whitney U test for self-efficacy to deal with the child's lifestyle behavior problems according to children with and without overweight-obesity

\begin{tabular}{|c|c|c|c|c|c|}
\hline \multirow{3}{*}{ Behavior Problem } & \multicolumn{4}{|c|}{ Self-efficacy } & \multirow{3}{*}{$p$} \\
\hline & \multicolumn{2}{|c|}{ With OW-OB } & \multicolumn{2}{|c|}{ Without OW-OB } & \\
\hline & MR & SR & MR & SR & \\
\hline 1. Eats too quickly & 107 & 7,449 & 147 & 30,226 & .001 \\
\hline 2. Eats too much & 113 & 7,862 & 145 & 29,813 & .004 \\
\hline 3. Eats unhealthy snacks & 109 & 7,586 & 146 & 30,089 & .001 \\
\hline 4. Whinges or whines about food & 122 & 8,473 & 142 & 29,202 & .065 \\
\hline 5. Yells about food & 122 & 8,470 & 142 & 29,205 & .058 \\
\hline 6. Throws a tantrum about food & 116 & 8,059 & 144 & 29,615 & .009 \\
\hline 7. Refuses to eat certain foods & 112 & 7,793 & 145 & 20,882 & .002 \\
\hline 8. Argues about food & 107 & 7,385 & 147 & 30,289 & .001 \\
\hline 9. Demands extra helpings at meals & 103 & 7,163 & 148 & 30,511 & .001 \\
\hline 10. Requests food continuously between meals & 110 & 7,654 & 146 & 30,020 & .001 \\
\hline 11. Demands food when shopping or on outings & 107 & 7,431 & 147 & 30,244 & .001 \\
\hline 12. Sneaks food when they know they are not supposed to & 113 & 7,827 & 145 & 30,244 & .001 \\
\hline 13. Hides food & 113 & 7,797 & 145 & 29,878 & .001 \\
\hline 14. Steals food from other children & 123 & 8,555 & 142 & 29,120 & .050 \\
\hline 15. Eats food to comfort themselves when feeling let down or depressed & 113 & 7,844 & 145 & 29,831 & .001 \\
\hline 16. Watches too much television & 109 & 7,557 & 146 & 30,118 & .001 \\
\hline 17. Spends too much time playing video or computer games & 106 & 7,355 & 147 & 30,319 & .001 \\
\hline 18. Complains about doing physical activity & 117 & 8,090 & 144 & 29,585 & .008 \\
\hline 19. Refuses to do physical activity & 127 & 8,801 & 140 & 28,874 & .182 \\
\hline 20. Complains about being unfit & 130 & 8,993 & 139 & 28,682 & .322 \\
\hline 21. Complains about being overweight & 134 & 9,246 & 138 & 28,428 & .611 \\
\hline 22. Complains about being teased & 134 & 9,312 & 138 & 28,363 & .719 \\
\hline 23. Complains about not having enough friends & 125 & 8,650 & 141 & 29,025 & .091 \\
\hline 24. Complains about being unattractive & 136 & 9,395 & 137 & 28,180 & .844 \\
\hline 25. Complains about not fitting into clothes & 130 & 8,997 & 139 & 28,678 & .308 \\
\hline
\end{tabular}

*Note: $O W-O B=$ Overweight-Obesity; $M R=$ Mean Range; $S R=$ Sum of Ranges; $U=$ Mann-Whitney; $p=$ Significance

Source: Own elaboration. 
Table 5. Single-factor ANOVA test for the child's lifestyle behavior problems according to MPCW

\begin{tabular}{|c|c|c|c|c|c|}
\hline Behavior Problem & $\boldsymbol{n}$ & $\overline{\boldsymbol{X}}$ & $\boldsymbol{S D}$ & $\boldsymbol{F}$ & $\boldsymbol{p}$ \\
\hline \multicolumn{7}{|c|}{ MPCW through words } \\
\hline Adequate & 14 & 63.14 & 18.14 & \multirow{2}{*}{17,041} & .001 \\
\hline Inadequate & 260 & 49.67 & 11.49 & & \multirow{2}{*}{.346} \\
\hline Adequate & 2 & 58.50 & 3.530 & \multirow{2}{*}{.891} & \\
\hline Inadequate & 272 & 50.30 & 12,261 & & \\
\hline
\end{tabular}

*Note: $\bar{X}=$ Mean; $\mathrm{SD}=$ Standard Deviation; $\mathrm{F}=$ Variance; $\mathrm{p}=$ Significance

Source: Own elaboration.

Table 6. Mann-Whitney U test for self-efficacy according to MPCW through words and images regarding overweight-obesity in the child

\begin{tabular}{|c|c|c|c|c|c|}
\hline Self-efficacy & $\boldsymbol{N}$ & MR & SR & $\boldsymbol{U}$ & $\boldsymbol{p}$ \\
\hline \multicolumn{7}{|c|}{ MPCW through words } \\
\hline Adequate & 14 & 87.36 & 1,223 & \multirow{2}{*}{1,118} & \multirow{2}{*}{.015} \\
\hline Inadequate & 260 & 140.20 & 36,452 & & \multirow{2}{*}{.875} \\
\hline Adequate & 2 & 128.75 & 257 & \multirow{2}{*}{254} & \\
\hline Inadequate & 272 & 137.56 & 34,417 & & \\
\hline
\end{tabular}

*Note: $U=$ Mann-Whitney; $p=$ Significance

Source: Own elaboration.

to a study conducted with mothers of children aged from 4 to 11 years old living in Australia (21). However, a study conducted in the Netherlands with mothers and fathers of children aged from 3 to 13 years old (14) and another study conducted in Sweden with mothers and fathers of preschool and school children (22) found that the mothers of children with overweight-obesity obtained the highest scores in the CLBPs subscale, whereas in the SE scale, no significant difference was identified according to the groups with and without overweight-obesity

Regarding the individual analysis by items, the mothers of children with overweight-obesity presented higher scores in 10 of the 25 CLBPs. It is worth noting that the study conducted in Swe- den (22) identified a significant difference in 20 out of 25 CLBPs, and that the survey conducted in Australia (21) did so in 24 out of 28 CLBPs. Lower scores were identified in 15 of the 25 SE items in mothers of children with overweight-obesity. The study conducted with mothers in Sweden (22) identified a significant difference in 7 out of 25 items and, in Australia (21), there was a significant difference in 26 out of 28 items.

Among the Mexican mothers of children with overweight-obesity, the CLBP that obtained the highest score was that of watches too much television, followed by eats too quickly. For the Australian (21) and Swedish mothers, the highest scores were in eats too much and watches too much television (22). Regarding SE, in 
the Mexican mothers the lowest score was in the demands extra helpings at meals item and, for the Australian (21) and Swedish mothers, it was eats too much (22). These findings have important implications, since one of the main factors related to excess weight is the increased consumption of calories, a factor that was not pointed out by the Mexican mothers, who, in addition, present less SE when their children demand extra helpings at meals.

Likewise, it was found that, when the perception of the child's overweight-obesity is adequate, higher CLBPs scores and lower SE values are presented; the aforementioned when MPCW is evaluated through words. A possible explanation as to why no difference was found between the CLBPs and SE variables and MPCW through images is that the latter was assessed with a panel consisting in 7 images, which do not represent categories defined by body weight. In addition, the mothers of children with overweight-obesity could select 2 possible options for MPCW to be adequate (18).

Other authors point out that, up to date, the best method to assess MPCW has not yet been established, and add that images are useful to help sensitize the parents regarding excess weight in childhood (23). However, as these images are not shown to the parents along with weight categories, they do not allow them to recognize the child's weight in a category, as is the case with MPCW through words.

This finding is significant and further exploration is recommended, since the studies conducted in adolescents and adults have found that, when there is an adequate perception of overweight-obesity, depression and lower quality of life can emerge (17). Likewise, although the recommendation is to promote adequate MPCW in mothers of children with overweightobesity, it is necessary to explore if, when more child's CLBPS and less SE to deal with them are perceived, depression and stress could emerge, variables related to unhealthy upbringing practices and to childhood obesity (24).

In addition, the literature indicates that the mothers who feel sufficiently confident to achieve the expected outcomes might not initiate actions or get involved in programs targeted at preventing and treating excess weight in their children (25). A negative and significant relationship has also been documented between SE, restrictive eating practices, and pressure to eat (26), which could result in children gaining weight.

Among the strengths of this study, we can point out that the children's nutritional status was obtained from the Body Mass Index measured and that the Lifestyle Behaviour Checklist questionnaire (12) showed acceptable internal consistency. One of the limitations is that only mothers participated; therefore, seeking the fathers' contribution is an opportunity area (27). In addition, this study did not identify determining factors of adequate MPCW in the mothers of children with overweight-obesity, as well as it did not analyze if some maternal-child sociodemographic characteristics were related to the CLBPs and to SE to deal with them.

\section{Conclusions and recommendations}

It is concluded that the mothers of children with overweightobesity present inadequate MPCW, underestimate their children's weight, report more CLBPs in the children and less SE to deal with them. Likewise, when overweight-obesity in the child is perceived, more CLBPs are presented, as well as less SE to deal with them.

It is recommended to replicate this study in other populations with children belonging to a broader age group, as well as to explore the relationship between the perception of the child's overweight-obesity and variables such as depression, stress, eating habits, and physical activity. It is also suggested to study the relationship between self-efficacy and the promotion of healthy habits in the family, a situation that was not assessed in this research. Finally, it is also recommended to devise interventions to promote adequate MPCW and maternal acknowledgment of excess eating as a factor related to childhood obesity, mainly in mothers of children with overweight-obesity, in addition to strengthening SE to initiate actions targeted at preventing and treating excess weight in childhood.

The authors declare no conflict of interest. 


\section{References}

1. Organización Mundial de la Salud. Sobrepeso y obesidad infantiles [Internet]. Organización Mundial de la Salud; 2020 [citado 2021 may 21]. Disponible en: http://www.who.int/dietphysicalactivity/childhood/es/

2. Kumar S, Kelly AS. Review of Childhood Obesity: From Epidemiology, Etiology, and Comorbidities to Clinical Assessment and Treatment. Mayo Clin Proc. 2017; 92(2):251-265. DOI: https://doi.org/10.1016/j.mayocp.2016.09.017

3. Chatham RE, Mixer SJ. Cultural Influences on Childhood Obesity in Ethnic Minorities: A Qualitative Systematic Review. J Transcult Nurs. 2020; 31(1):87-99. DOI: https://doi.org/10.1177/1043659619869428

4. Lee EY, Yoon KH. Epidemic obesity in children and adolescents: risk factors and prevention. Front Med. 2018; 12(6):658666. DOI: https://doi.org/10.1007/s11684-018-0640-1

5. Martinez SM, Rhee KE, Blanco E, Boutelle K. Latino mothers' beliefs about child weight and family health. Public Health Nutr. 2017; 20(6):1099-106. DOI: https://doi.org/10.1017/S1368980016002962

6. Gregori D, Hochdorn A, Azzolina D, Berchialla P, Lorenzoni G, OBEY-AD Study Consortium. Does love really make mothers blind? A large transcontinental study on mothers' awareness about their children's weight. Obes Silver Spring Md. 2018; 26(7):1211-24. DOI: https://doi.org/10.1002/oby.22214

7. Blanchet R, Kengneson C-C, Bodnaruc AM, Gunter A, Giroux I. Factors Influencing Parents' and Children's Misperception of Children's Weight Status: a Systematic Review of Current Research. Curr Obes Rep. 2019; 8(4):373-412. DOI: https:// doi.org/10.1007/s13679-019-00361-1

8. Cheng TS, Loy SL, Cheung YB, Chan JKY, Tint MT, Godfrey KM, et al. Singaporean Mothers' Perception of Their Threeyear-old Child's Weight Status: A Cross-Sectional Study. PLoS ONE. 2016; 11(1):e0147563. DOI: https://doi.org/10.1371/ journal.pone.0147563

9. Queally M, Doherty E, Matvienko-Sikar K, Toomey E, Cullinan J, Harrington JM, et al. Do mothers accurately identify their child's overweight/obesity status during early childhood? Evidence from a nationally representative cohort study. Int J Behav Nutr Phys Act. 2018; 15(1):56. DOI: https://doi.org/10.1186/s12966-018-0688-y

10. Hidalgo-Mendez J, Power TG, Fisher JO, O’Connor TM, Hughes SO. Child weight status and accuracy of perceived child weight status as predictors of Latina mothers' feeding practices and styles. Appetite. 2019; 142:104387. DOI: https:// doi.org/10.1016/j.appet.2019.104387

11. Gauthier KI, Gance-Cleveland B. Hispanic parents' perceptions of their preschool children's weight status. J Spec Pediatr Nurs. 2016; 21(2):84-93. DOI: https://doi.org/10.1111/jspn.12143

12. West F, Sanders MR. (2015). Lifestyle Behaviour Checklist. Brisbane: Parenting and Family Support Centre. The University of Queensland.

13. West F, Morawska A, Joughin K. The Lifestyle Behaviour Checklist: evaluation of the factor structure. Child Care Health Dev. 2010; 36(4):508-15. DOI: https://doi.org/10.1111/j.1365-2214.2010.01074.x

14. Gerards SMPL, Hummel K, Dagnelie PC, de Vries NK, Kremers SPJ. Parental self-efficacy in childhood overweight: validation of the Lifestyle Behavior Checklist in the Netherlands. Int J Behav Nutr Phys Act. 2013; 10:7. DOI: https://doi. org/10.1186/1479-5868-10-7

15. Cook DA, Artino AR Jr. Motivation to learn: an overview of contemporary theories. Med Educ. 2016; 50(10):997-1014. DOI: https://doi.org/10.1111/medu.13074

16. Hong SA, Peltzer K, Jalayondeja C. Parental misperception of child's weight and related factors within family norms. Eat Weight Disord. 2019; 24(3):557-564. DOI: https://doi.org/10.1007/s40519-017-0399-4

17. Robinson E. Overweight but unseen: a review of the underestimation of weight status and a visual normalization theory. Obes Rev. 2017; 18(10):1200-1209. DOI: https://doi.org/10.1111/obr.12570

18. Eckstein KC, Mikhail LM, Ariza AJ, Thomson JS, Millard SC, Binns HJ, et al. Parents' perceptions of their child's weight and health. Pediatrics. 2006; 117(3):681-90. DOI: https://doi.org/10.1542/peds.2005-0910 
19. World Health Organization. Anthro Survey Analyser and other tools [Internet]. World Health Organization; 2020 [citado 2021 may 21]. Disponible en: http://www.who.int/childgrowth/software/en/

20. Flores-Peña Y, Rocha-Aguirre LL, Cárdenas-Villarreal VM, Haslam D, Mejia A, Sanders M. Conductas del estilo de vida del hijo relacionadas con el peso y autoeficacia materna para manejarlas. Nutr Hosp. 2015; 32(1):144-150. DOI: https:// doi.org/10.3305/nh.2015.32.1.8855

21. West F, Sanders MR. The lifestyle behaviour checklist: a measure of weight-related problem behaviour in obese children. Int J Pediatr Obes. 2009; 4(4):266-73. DOI: https://doi.org/10.3109/17477160902811199

22. Ek A, Sorjonen K, Nyman J, Marcus C, Nowicka P. Child behaviors associated with childhood obesity and parents' selfefficacy to handle them: Confirmatory factor analysis of the Lifestyle Behavior Checklist. Int J Behav Nutr Phys Act. 2015; 12(1):36. DOI: https://doi.org/10.1186/s12966-015-0194-4

23. Garcia ML, Crespo NC, Behar AI, Talavera GA, Campbell N, Shadron LM, Elder JP. Examining Mexican-Heritage Mothers' Perceptions of Their Children's Weight: Comparison of Silhouette and Categorical Survey Methods. Child Obes. 2020; 16(1):44-52. DOI: https://doi.org/10.1089/chi.2019.0015

24. Jang M, Owen B, Lauver DR. Different types of parental stress and childhood obesity: A systematic review of observational studies. Obes Rev. 2019; 20(12):1740-1758. DOI: https://doi.org/10.1111/obr.12930

25. Chen J-L, Guo J, Esquivel JH, Chesla CA. Like mother, like child: the influences of maternal attitudes and behaviors on weight-related health behaviors in their children. J Transcult Nurs. 2018; 29(6):523-31. DOI: https://doi. org/10.1177/1043659617736883

26. Camfferman R, Van der Veek SMC, Rippe RCA, Mesman J. Maternal feeding practices, health cognitions, and children's eating styles and weight status. J Dev Behav Pediatr. 2019; 40(2):122-30. DOI: https://doi.org/10.1097/ DBP.0000000000000640

27. Penilla C, Tschann JM, Deardorff J, Flores E, Pasch LA, Butte NF, et al. Fathers' feeding practices and children's weight status in Mexican American families. Appetite. 2017; 117:109-16. DOI: https://doi.org/10.1016/j.appet.2017.06.016 